\title{
Effect of Ferrous Gluconate on Chromosomal Abnormality Index of Allium Cepa Root Tip
}

\begin{abstract}
Nergis Kaya ${ }^{1, a, *}$
${ }^{1}$ Department of Food Processing, Food Technology Program, Biga Vocational School, Çanakkale Onsekiz Mart University, 17200 Çanakkale, Turkey *Corresponding author

A R T I C L I N F O A B S T R A T

Research Article

In completed research, ferrous gluconate -a food additive- used to preserve black color to prevent discoloration during storage in ripe black olives, and Allium cepa L. species. A. cepa L. roots were treated with different doses of ferrous gluconate. The effective concentration $\mathrm{EC}_{50}(0.068 \mathrm{~g} / \mathrm{l})$ was determined. A. cepa root tips were treated with $\mathrm{EC}_{50} / 2(0.034 \mathrm{~g} / \mathrm{l}), \mathrm{EC}_{50}(0.068 \mathrm{~g} / \mathrm{l}), 2 \mathrm{XEC}_{50}(0.136$ $\mathrm{g} / \mathrm{l})$ dose for $24,48,72$ hours, and afterward, the root tips were prepared for observation under the light microscope according to the method of preparing mitotic preparation. Chromosomal abnormality index (CAI) and genotoxic effect of ferrous gluconate in A. cepa root tip cells were determined. Repeated measurement ANOVA and TUKEY multiple comparison tests were used to investigate the effect of time and dose together on genotoxicity. C-mitosis, polyploidy, polar shifting in anaphase, polar shifting in telophase, equatorial plate shifting, laggard chromosome was observed by microscope. The highest CAI (70.16 \pm 4.85$)$ was observed at $72 \mathrm{~h}$ for $2 \mathrm{XEC}_{50}$ dose. Chromosomal aberration is also observed in control group. While the most common chromosomal aberration is determined as C-mitosis; The least observed chromosomal aberration is determined as polyploidy. Research results revealed that ferrous gluconate has a genotoxic effect on the root tip of A. cepa.

Keywords:

Allium cepa test

Ferrous gluconate

Genotoxicity

Chromosome aberration

Allium cepa L.
\end{abstract}

nergisskkaya@gmail.com (i) https://orcid.org/0000-0002-4206-1149|

(c) (1) () Te This work is licensed under Creative Commons Attribution 4.0 International License

\section{Introduction}

Significant increases were observed consuming of food preservatives in the $20^{\text {th }}$ century with the increase in food production (Altuğ, 2001). Food preservatives are defined as substances used to effect properties of food as requested. Natural preservatives have been used since the past; artificial preservatives have been used which reduce the fee with the development of technology and accelerating of production in recent years (Gürsoy, 2001). These are the application forms of food additives that create the desired effect, such as preventing the bad taste of the food or the production of faulty products, etc (Altuğ, 2001). It is important to consider that even if the food additives used are not harmful to health, it may cause damage to tissues and accumulate in the body over time. So, these food preservatives might threaten human health as indirect or direct. Because of the risks, clastogenic, mutagenic, aneugenic effects of various substances including food preservatives are investigated by in vivo and in vitro tests. Many studies were indicated a positive correlation between the mutagenic effects of chemicals and the risk of cancer (Kaderlik et. al., 1992; van Sittert et. al., 2000; Moore and
Chen, 2006; Maertens et. al., 2008; Prado-Ochoa et. al., 2020).

The color of black olives is not permanent, it is gradually disappearing after oxidation and over the life of the packaged product. Iron salts (ferrous gluconate, ferrous sulphate, ferrous lactate) are used to prevent this degradation (Cruess, 1962). Ferrous gluconate (E579) is a food additive which is well soluble in water (Hurrell, 1997) and it consists of iron and glucose. This food additive is used to preserve the black color after the darkening step in order to prevent color degradation during storage of ripe black olives (Garcia et al., 1986; Anonymous, 1995). Plant test systems have a common usage in evaluating the genetic aberrations caused by different chemicals. A. cepa test is being used by many explorers as bioindicators in effect assessment of chemicals (Bagatini et al., 2009; Leme and Marin-Morales, 2009). Allium cepa test can predict possible damage to the DNA of eukaryotes, therefore Allium cepa test is valuable (Tedesco and Laughinghouse, 2012). It was indicated that the A. cepa test correlates well with mammalian test systems (Fiskesjö, 1985). 
The decreasing mitotic index indicates inhibition of the cell cycle and decreased proliferative of the cells (Gökalp Muranl1, 2006).

In this study, genotoxicity caused by ferrous gluconate in the mitotic division cells in $A$. cepa $\mathrm{L}$. $(2 \mathrm{n}=16)$ root tips were researched. At the beginning, the $\mathrm{EC}_{50}$ value was determined, afterward, ferrous gluconate was applied to the root tips for $24,48,72$ hours at $\mathrm{EC}_{50} / 2, \mathrm{EC}_{50}, 2 \mathrm{XEC}_{50}$ concentration. Thus, genotoxic effect of ferrous gluconate was evaluated.

\section{Materials and Methods}

\section{Material}

In study, A. cepa L. $(2 \mathrm{n}=16)$ was used. Ferrous gluconate (E579) used as a food additive was supplied from Cesa Chemical Industry Trade Limited Company.

\section{Method}

Treatment of Root Tips with $E C_{50}$ Concentrations

In the first place, A. серa L. root tips were applied with different concentrations prepared by dissolving ferrous gluconate in water (0.16- 0.20- 0.30- 0.35- 0.40- 0.50- 0.60$0.70 \mathrm{~g} / \mathrm{l})$. Root tip lengths were measured and $\mathrm{EC}_{50}$ concentration was determined. (Fiskesjö, 1993). A. сера L. roots were treated with $\mathrm{EC}_{50} / 2(0.034 \mathrm{~g} / \mathrm{l}), \mathrm{EC}_{50}(0.068 \mathrm{~g} / \mathrm{l})$, $2 \mathrm{XEC}_{50}(0.136 \mathrm{~g} / \mathrm{l})$ concentrations for $24,48,72 \mathrm{~h}$.

\section{Preparation of Mitotic Preparations}

At the end of the application period, root tips were cut and put into the farmer's fixative. The root tips were washed with water and hydrolyzed as expressed by Souguir et al. (2008). Samples were stained with $2 \%$ acetocarmine (w/v). For all treatment groups, at least 5000 cells were counted. Prophase, metaphase, anaphase and telophase cells were observed by the light microscope and root tips were evaluated.

Chromosomal abnormality index (CAI) was calculated by the formula $\mathrm{CAI}=$ Number of cells with chromosomal abnormalities/total cells number.

\section{Statistical Analysis}

Repeated Measurement ANOVA and The TUKEY Multiple Comparison Tests were used.

\section{Results and Discussion}

Mitotic phases (prophase, metaphase, anaphase and telophase) and chromosomal aberrations were observed at root tips after treatment of ferrous gluconate at doses of $\mathrm{EC}_{50} / 2, \mathrm{EC}_{50}, \mathrm{EC}_{50} \mathrm{X} 2$ to $A$. cepa root tips for 24,48 and 72 hours. In addition, chromosomal aberration index (\%) were given together with the mean and standard errors (Table 1).

It has been determined that the difference between concentrations varies according to the duration of treatment. It was detected that ferrous gluconate causes chromosomal abnormalities such as C-mitosis, equatorial shifting, polar shifting, laggard chromosome, chromosomal fragment and polyploidy in A. cepa root tip cells (Figure 1). In terms of chromosomal aberration index, it was determined that the duration of treatment period didn't affect the control group. The highest chromosomal aberration index was determined for $\mathrm{EC}_{50} \mathrm{X} 2$ dose at 72 hours. In this way, it has been shown that ferrous gluconate has genotoxic effect (Table 1).

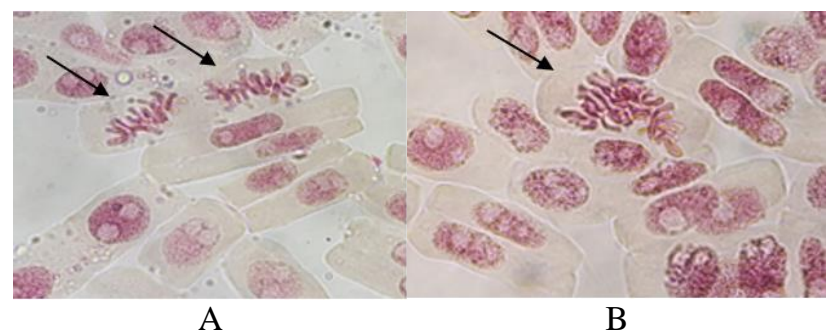

A

B
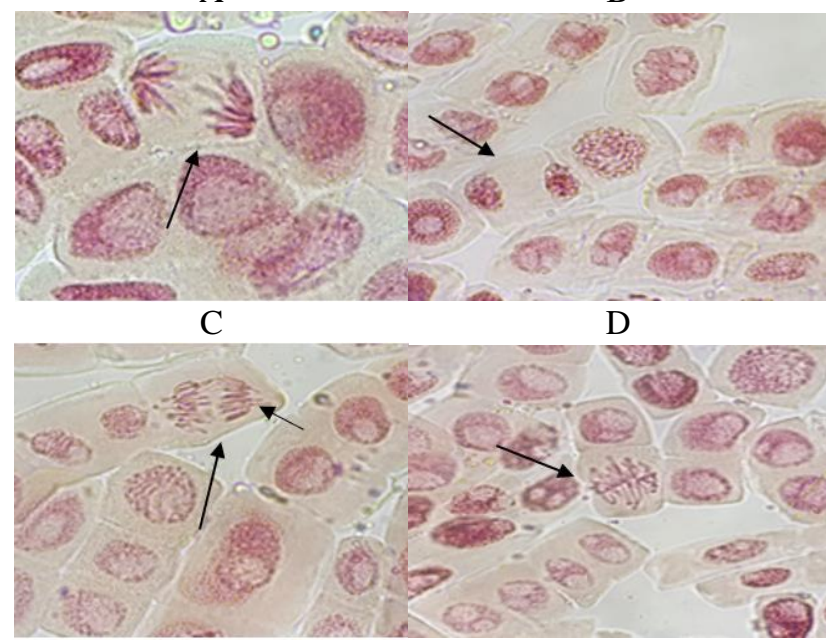

E

F

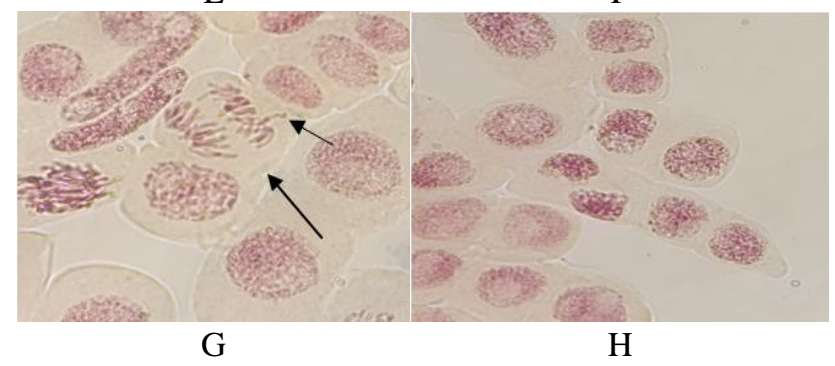

Figure 1. Photographs of chromosomal abnormalities observed in mitotic phases in root tip cells as a result of ferrous gluconate application to root tips of A. cepa are shown.

It was determined that usage of orange $\mathrm{G}$ and brillant blue (Kumar and Sing, 2017); sodium saccharin and sodium cyclamate food sweeteners (Oliveira et al. 2017); synthetic sweeteners passion fruit and vanilla (Nunes et al, 2017); tartrazine (Lerda, 2017) was caused chromosomal aberrations due to concentration and increasing application time in root tip cells. Thus, it has been shown that the mentioned food additives have genotoxic effect. It has been shown that doses of cookies and tutti-frutti aroma and combined doses of these sweeteners induce chromosomal abnormalities in a significant number of cells at the root tip of A. cepa. Therefore, it was indicated the cookie flavor and the combined doses are genotoxic; tutti-frutti aroma showed genotoxic effect. Brillant blue and sunset yellow have been found to have genotoxic effect (Kuş and Eroğlu ,2015). Tripathy and Rao (2015) found that orange red food colorant caused mitotic aberrations in A. cepa L. root tip cells. It was determined that chromosomal aberration index increased at the root tip, when applied with sunset yellow azo dye (Dwivedi and Kumar, 2015); benzoate and boric acid (Kumar and Pandey, 2015); sodium nitrate, butylated hydroxyanisole, sorbic acid, butylated hydroxytoluene and propyl gallate (Pandey et al., 2014). Pandey et al. (2014) found that the total percentage of chromosomal aberrations increased with increasing dose and treatment time. 
Table 1. Chromosome aberration \%, total aberration (Mean \pm Std. Error) in root meristem cells of $A$. cepa after exposure $\mathrm{EC}_{50} / 2, \mathrm{EC}_{50}$ and $\mathrm{EC}_{50} \mathrm{X} 2$ ferrous gluconate dose for 24,48 and $72 \mathrm{~h}$

\begin{tabular}{|c|c|c|c|c|c|c|c|c|}
\hline \multirow{2}{*}{ Treatment period $(\mathrm{h})$} & \multirow{2}{*}{ Dose $(\mathrm{g} / \mathrm{l})$} & \multicolumn{6}{|c|}{ Chromosome aberrations (\%) } & \multirow{2}{*}{ Total aberration $\%$ (Mean \pm Std. Error) } \\
\hline & & C-Mit & E.Pl Sh & $\mathrm{Pl} \mathrm{Sh}$ & Lag & Chrl F & Polip & \\
\hline \multirow{4}{*}{24} & Control & 30 & 21.67 & 10 & 18.33 & 0 & 0 & $1.482 \pm 0.462^{\mathrm{Ca}}$ \\
\hline & $\mathrm{EC} 50 / 2$ & 38.62 & 24.99 & 33.34 & 29.7 & 1.51 & 0 & $13.717 \pm 0.576^{\mathrm{Bc}}$ \\
\hline & EC50 & 42.99 & 14.63 & 22.42 & 16.45 & 0 & 0 & $20.546 \pm 0.683^{\text {BAa }}$ \\
\hline & EC50X2 & 9 & 16.53 & 23.12 & 14.59 & 0 & 0 & $26.524 \pm 0.787^{\mathrm{Aa}}$ \\
\hline \multirow{4}{*}{48} & Control & 42 & 20 & 0 & 18 & 0 & 0 & $1.286 \pm 0.496^{\mathrm{Ca}}$ \\
\hline & EC50/2 & 41.65 & 15.16 & 20.25 & 22.02 & 0 & 0 & $33.99 \pm 1.28^{\mathrm{Bb}}$ \\
\hline & EC50 & 43.48 & 15.77 & 33.95 & 19.39 & 0 & 0 & $41.14 \pm 2.52^{\mathrm{BCb}}$ \\
\hline & EC50X2 & 32.43 & 19.44 & 31.22 & 13.13 & 3.11 & 2.1 & $45.973 \pm 0.593^{\mathrm{Ab}}$ \\
\hline \multirow{4}{*}{72} & Control & 33.33 & 0 & 0 & 6.67 & 0 & 0 & $0.486 \pm 0.359^{\mathrm{Ca}}$ \\
\hline & EC50/2 & 40.26 & 14.82 & 21.47 & 17.93 & 1.51 & 0 & $51.603 \pm 0.792^{\mathrm{Ba}}$ \\
\hline & EC50 & 40.54 & 13.73 & 32.31 & 8.2 & 4.95 & 1.2 & $53.46 \pm 6.12^{\mathrm{Ba}}$ \\
\hline & EC50X2 & 20.04 & 19.06 & 34.71 & 26.41 & 1.38 & 0 & $70.16 \pm 4.85^{\mathrm{Aa}}$ \\
\hline
\end{tabular}

Note 1. The difference between the doses indicated in different capital letters during the same period is important. Note 2 . The difference between treatment period indicated in different small letters at the same dose is important.

It was determined that tartrazine and sunset yellow (Dwivedi and Kumar, 2017); monosodium glutamate (Adeyemo and Farinmade, 2013); sunset yellow, bordeaux, tartrazine (Gomes and Oliveira, 2013); monosodium glutamate, monopotassium glutamate, calcium glutamate, monoammonium glutamate, magnesium diglutamate flavor enhancers (Türkoğlu, 2013); potassium metabisülfit and potasium nitrate (Gömürgen, 2005) increased chromosomal aberrations. It was reported that trisodium phosphate, disodium phosphate and monosodium phosphate (Türkoğlu, 2009), potassium propionate, calcium propionate and sodium propionate (Türkoğlu, 2008); boric acid, sodium citrate, sodium benzoate, potassium citrate and citric acid (Türkoğlu, 2007) inhibited cell division. In addition to this, it was reported that those food preservatives increased chromosome aberrations. In parallel with these studies, it was determined that chromosomal aberration index increased due to increasing in dose and treatment period by treating different concentration of ferrous gluconate at different periods. Similar to these researches, it was reported that it has been observed chromosomal aberrations such as C-mitosis (Nunes et al., 2017; Kumar and Pandey, 2015; Türkoğlu, 2013, 2009, 2007; 2008; Dwivedi and Kumar, 2007; Gömürgen, 2004), laggard chromosome (Dwivedi and Kumar, 2015, 2017; Kumar and Pandey, 2015; Türkoğlu, $2013,2008,2007)$ in mitotic cells. In addition to these aberrations, some other aberrations (polar shifting, equatorial table shifting etc.) were detected in mitotic cells in this research.

\section{Conclusion}

In the result of this research, it was determined that ferrous gluconate may cause genotoxicity to living organisms when exposed to more than certain doses and periods. This effect occurs by inhibiting mitosis and causing chromosomal abnormalities. Genotoxic effects determined by $A$. серa test can be generalized to all living organisms. Therefore, it should be noted that the use of ferrous gluconate in foods may have toxic effects on humans over certain doses and treatment periods.

\section{Acknowledgement}

This research project which numbered as FBA-20181443 was supported by Canakkale Onsekiz Mart University Commission of Scientific Research Projects.

\section{References}

Adeyemo OA, Farinmade AE. 2013. Genotoxic and cytotoxic effects of food flavor enhancer, monosodium glutamate (MSG) using Allium cepa assay. Afr J Biotechnol, 12(13): 1459-1466.

Adeyemo OA, Farinmade AE. 2013. Genotoxic and cytotoxic effects of food flavor enhancer, monosodium glutamate (MSG) using Allium cepa assay. Afr J Biotechnol, 12(13): 1459-1466.

Altuğ T. Gıda Katkı Maddeleri, Meta Basım, İzmir. 2001. p. 286.

Amer SM, Aly FA. 1992. Cytogenetic effects of pesticides. 1v. cytogenetic effects of the insecticides gardona and dursban. Mut Res, 279(3): 165-170.

Anderson D, Jenkinson PC, Dewdeney RS, Franis AJ, Godbert P, Butterworth KR. 1988. Chromosome aberrations, mitogeninduced blastogenesis and proliferative rate index in peripheral lymphocytes from 106 control individuals of UK. population. 1988; Mutat Res, 204(3): 407-20.

Anonymous 1995. code of federal regulations. office of the federal register national archives and records administration, Washington, DC.

Arslan M. 2004. Borik asit'in insan periferal lenfositlerinde in vitro kromozom aberasyonu ve kardeş kromatid değişimi üzerindeki etkileri. Science Institute, Cukurova University, Adana, Turkey.

Bagatini MD, Fachinetto JM, Silva ACF, Tedesco SB. 2009. Cytotoxic effects of infusions (tea) of Solidago microglossa DC. (Asteraceae) on the cell cycle of Allium cepa. Braz J Pharmacogn, 19(2B): 632-636.

Bakare AA, Mosuro AA, Osibanjo O. 2000. Effect of simulated leachate on chromosomes and mitosis in roots of Allium cepa (L). J Environ Biol, 21(3): 263-271.

Chauhan LKS, Saxena PN, Gupta SK. 1999. Cytogenetic effects of cypermethrin and fenvalerate on the root meristem cells of Allium cepa. Environ Exp Bot, 42(3): 181-189.

Cruess WV. 1962. Experiments on color fixation with iron salts, in 41 Annual Technical Report of California Olive Association, Sacramento. California, USA. p. 1-13.

Dwivedi H, Kumar G. 2017. Genomic distortion induced by food dyes on meristematic cells of Trachyspermum ammi (L.) Sprague (Ajwain). Chromosome Botany, 12(3): 46-51. 
Dwivedi K, Kumar G. 2015. Genetic damage induced by a food coloring dye (sunset yellow) on meristematic cells of Brassica campestris L. Int J Environ Res Public Health. 2015: 1-5.

Fiskesjö G. 1985. The Allium-test as a standard in environmental monitoring. Hereditas. 102(1): 99-112.

Fiskesjö G. 1993. The Allium cepa test in wastewater monitoring. Environ Toxic Water, 8(3): 291-298.

Garcia P, Brenes M, Garrido A. 1986. Use of ferrous lactate in the elaboration of ripe olives. Grasas Aceites. 37(1): 33-38.

Gomes KMS, Oliveira MVGA. 2013. Citotoxicity of food dyes Sunset Yellow (E-110), Bordeaux Red (E-123), and Tatrazine Yellow (E-102) on Allium cepa L. Root Meristematic Cells. Food Sci Technol (Campinas), 33(1): 218-223.

Gökalp Muranlı FD. 2006. Kültürü Yapılan İnsan Lenfositlerinde Triasulfuron'un Genotoksik Etkileri. Trakya University, Science Institute, Edirne, Turkey.

Gömürgen AN. 2005. Cytological effect of the potassium metabisulphite and potassium nitrate food preservative on root tips of Allium cepa L. Cytologia, 70(2): 119-128.

Gürsoy S. 2001. Besinlerde katkı maddelerinin kullanımı ve sitrik asit toksisitesi. Science Institute, Trakya University, Trakya, Turkey.

Hurrell RF. 1997. Preventing iron deficiency through food fortification. Nutr Rev, 55(6): 210-222.

Kaderlik RK, Lin DX, Long NP. 1992. Advantages and limitation of laboratory methots for measurement of carcinogen DNA adducuts for epilogical studies. Toxicol Lett, 64-65(469-75): 469-475.

Kayraldız A, Topaktaş M. 2007. The in vivo genotoxic effects of sodium metabisulfite in bone marrow cells of rats. Russ $\mathrm{J}$ Genet, 43(8): 905- 909.

Kumar G, Pandey A. 2015. Genotoxic and mito-depressive effects of food preservatives on root meristems of barley (Hordeum vulgare L.). Chromosome Botany, 10(2): 51-60.

Kumar G, Singh S. 2017. Genotoxic effects of food dyes on mitotic chromosomal entity in root meristems of cluster bean (Cyamopsis tetragonoloba (L.) Taub.). IJCRGG, 10(13): 8189.

Kuş E, Eroğlu HE. 2015. Genotoxic and cytotoxic effects of sunset yellow and brilliant blue, colorant food additives, on human blood lymphocytes. Pak J Pharm Sci, 28(1): 227-30.

Leme DM, Marin-Morales MA. 2009. Allium cepa test in environmental monitoring: A review on its application. Mut Res, 682(1): 71-81.

Lerda D. 2017. The effects of tartrazine in Allium cepa LJ Food Nutr. 2017; 3(101): 1-5.

Maertens RM, Yang X, Zhu J, Gagne RW, Douglas GR, White PA. 2008. Mutagenic and carcinogenic hazards of settled house dust I: Polycyclic aromatic hydrocarbon content and excess lifetime cancer risk from preschool exposure. Environ sci technol, 42(5): 1747-1753.

Moore MM, Chen T. 2006. Mutagenicity of bromate: implications for cancer risk assessment. Toxicology, 221(23): 190-196.

Moura AG, Santana GM, Ferreirab PMP, Sousaa JMC, Peron AP. 2016. Cytotoxicity of cheese and cheddar cheese food flavorings on Allim cepa L root meristems. Braz. J Biol, 76(2): 439-443.
Nunes RDM, Sales I, Silva SIO, Sousa JMC, Peron AP. 2017. Antiproliferative and genotoxic effects of nature identical and artificial synthetic food additives of aroma and flavor. Braz. J Biol, 77(1): 150-154.

Oliveira VA, Oliveira VM, Oliveira TWN, Damasceno ANC, Silva CEO, Medeiros SRA, Soares BM, Silva FCC, Aguiar RPS, Islam M, Melo Cavalcante AAC, Peron AP, Sousa JMC. 2017. Evaluation of cytotoxic and mutagenic effects of two artificial sweeteners by using eukaryotic test systems. Afr J Biotechnol, 16(11): 547-551.

Pandey H, Vikas Kumar V, Roy BK. 2014. Assessment of genotoxicity of some common food preservatives using Allium cepa L. as a test plant. Toxicol Rep, 1(2014): 300-308.

Prado-Ochoa MG, Strassburger-Madrigal M, Camacho-Carranza R, Espinosa-Aguirre JJ, Velázquez-Sánchez AM, VázquezValadez VH, Muñoz-Guzmán MA. 2020. Structure-Activity Relationship (SAR) and in vitro Predictions of Mutagenic and Carcinogenic Activities of Ixodicidal Ethyl-Carbamates. Biomed Res Int, 2020: 1-8.

Rencüzoğulları E, Kayraldız A, Ila HB, Çakmak T, Topaktaş M. 2001. The cytogenetic effects of sodium metabisulfite, a food preservative in root tip cells of Allium cepa L. Turk J Biol, 25(4): 361-370.

Rojas E, Herrera LA, Sordo M, Gonsebatt ME, Montero R, Rodriguez R, Ostrosky-Wegman P. 1993. Mitotic index and cell proliferation kinetics for the identification of antineoplastic activity. Anti-Cancer Drug, 4(6): 637-40.

Seth CS, Chaturvedi PK, Misra V. 2007. Toxic effect of arsenate and cadmium alone and in combination on giant duckweed (Spirodela polyrrhiza L.) in response to its accumulation. Environ Toxicol, 22(6): 539-549.

Souguir D, Ferjani E, Ledoigt G, Goupil P. 2008. Exposure of Vicia faba and Pisum sativum to copper-induced genotoxicity. Protoplasma, 233(3-4): 203-207.

Tedesco SB, Laughinghouse HD. 2012. Bioindicator of genotoxicity: The Allium cepa test. Stud Environ Sci, 137156.

Tripathy SK, Rao DA. 2015. Mitotic aberrations induced by orange red (a food additive dye) as a potential genotoxicant on root tip cells of onion (Allium cepa L.). Int Food Res J, 22(1): 383-392.

Türkoğlu Ş. 2007. Genotoxicity of five food preservatives tested on root tips of Allium cepa L. MRGTEM, 626(1-2): 4-14.

Türkoğlu Ş. 2008. Evaluation of genotoxic effects of sodium propionate, calcium propionate and potassium propionate on the root meristem cells of Allium cepa. Food Chem Toxicol, 46(6): 2035-2041.

Türkoğlu Ş. 2009. Genotoxic effects of mono, di-and trisodium phosphste on mitotic activity, DNA content, and nuclear volume in Allium cepa L. Caryologia, 62(3): 171-179.

Türkoğlu Ş. 2013. Evaluation of genotoxic effects of five flavour enhancers (glutamates) on the root meristem cells of Allium cepa. Toxicol Ind Health, 31(9): 792-801.

Van Sittert NJ, Boogaard PJ, Natarajan AT, Tates AD, Ehrenberg LG, Törnqvist MA. 2000. Formation of DNA adducts and induction of mutagenic effects in rats following 4 weeks inhalation exposure to ethylene oxide as a basis for cancer risk assessment. Mutat Res-Fund Mol M, 447(1): 27-48. 